\title{
A revision of the genus Strongylodesma Lévi (Porifera: Demospongiae: Latrunculiidae) with descriptions of four new species
}

\author{
TOUFIEK SAMAAI ${ }^{1}$, MARK J. GIBBONS ${ }^{2}$ AND MICHELLE KELLY ${ }^{3}$ \\ ${ }^{1}$ Marine and Coastal Management, Ecosystem Utilisation and Conservation, P/B X2, Roggebaai, 8012, South Africa, ${ }^{2}$ Biodiversity \\ and Conservation Biology Department, University of the Western Cape, PO Box X17, Bellville, Cape Town, South Africa, ${ }^{3}$ National \\ Centre for Aquatic Biodiversity and Biosecurity, National Institute of Water and Atmospheric Research Limited, Private Bag 109 \\ 695, Newmarket, Auckland, New Zealand
}

\begin{abstract}
The sponge genus Strongylodesma is reviewed and redefined, and now accommodates eight closely related species. The type species of Strongylodesma Lévi is redescribed and an additional two new species are described from the Indo-Pacific: S. novaecaledoniae sp. nov. and S. tongaensis sp. nov. Several specimens previously identified as species of Batzella (Poecilosclerida: Chondropsidae) have been re-assigned to Strongylodesma, as the new species S. purpureus sp. nov. and S. nigra sp. nov. With the description here of new species from the Pacific Ocean and Caribbean Atlantic, the biogeographical distribution of Strongylodesma now appears to be generally tropical with a subtropical South African component, whereas previously it was only known from South Africa. Although species of Strongylodesma have not previously been recorded from the intermediate locations (Western Indian Ocean, South-east Asia, central west Pacific, and New Zealand), re-evaluation here will facilitate more readily the recognition of taxa in these intermediate regions, if they exist, in the future. The species are not widespread, except perhaps along the south-east coast of South Africa, and where they occur they are not abundant. Species occur over a wide depth range, from the intertidal in Tsitsikamma, South Africa, to $140 \mathrm{~m}$ in the Caribbean.
\end{abstract}

Keywords: Porifera, sponge, Demospongiae, Poecilosclerida, Latrunculiidae, Strongylodesma, taxonomy, new species, revision

Submitted 1 September 2008; accepted 22 October 2008

\section{INTRDロUCTION}

The genus Strongylodesma Lévi was erected by Lévi (1969) for a deep-water sponge, S. areolata Lévi, 1969, found on the Vema Seamount in the southern Atlantic Ocean, off the west coast of South Africa. The affinity of this genus with Latrunculia has now been firmly established (Samaai \& Kelly, 2002; Samaai et al., 2003, 2004; Antunes et al., 2005), yet in the past Strongylodesma was either unassigned (Lévi, 1969), incorrectly assigned (to Phoriospongiidae in Lévi, 1998), or the species was incorrectly assigned for convenience to the poorly recognized genera Prianos and Batzella, both of which only possess strongyles. Recent revisions of these two genera have revealed that the type species of Prianos has the skeletal architecture of a chalinid sponge (delicate unispicular isotropic reticulation of strongyles) and is a synonym of Haliclona (Reniera) (de Weerdt, 2002), and the type species of Batzella has skeletal characteristics (plumose columns of strongyles) shared with other Chondropsidae (Van Soest, 2002).

It is interesting to note that the presence in some specimens of strongyles with a 'looped end' or 'shepherd's crook' malformation, had also become associated with the incorrect assignment of some specimens of Strongylodesma to Batzella. This

Corresponding author:

T. Samaai

Email: tsamaai@deat.gov.za association is most likely due to the fact that the first record of this unique malformation was described from a species of Batzella from Curaçao (B. rosea Van Soest, 1984). The malformation is also seen in Caribbean and Pacific species of Strongylodesma, S. purpureus sp. nov. and S. nigra sp. nov, provisionally identified as Batzella by Van Soest (1996), and S. tongaensis sp. nov.

Thus, the accurate assignment of species with strongyles to Prianos, Batzella, or Strongylodesma, in the general taxonomic literature (e.g. de Laubenfels, 1954; Hoshino, 1981), and marine natural products literature (Sakemi et al., 1989; Sun et al., 1990; Van Soest et al., 1996; Gunasekera et al., 1999, 2003; see in Samaai \& Kelly, 2002 and Samaai et al., 2004), and in general biodiversity inventory (M. Kelly \& Lori J. Bell, CRRF, unpublished data), has proven difficult. The discovery of three new species of Strongylodesma from South Africa (Samaai et al., 2003, 2004) facilitated the clarification of a suite of diagnostic characters that now clearly define the genus Strongylodesma Lévi and confirm its monophyly. Strongylodesma has strongyles (smooth or terminally spined) arranged in a wispy polygonal reticulation within the choanosome, rather like that of Latrunculia, an ectosome composed of fibrillar collagen, green to brown coloration, hemispherical to encrusting morphology, an areolate aquiferous system with fungiform (mushroom-shaped) or concave porefields (Samaai \& Kelly, 2002), and all known species contain pyrroloquinoline alkaloids (Van Soest et al., 1996; 
Gunasekera et al., 2003; Antunes et al., 2004, 2005; Keyzers et al., 2004).

It was not until 2002 that Strongylodesma was reported from other locations than the type locality (Samaai \& Kelly, 2002) despite comprehensive shallow and deep water collections emerging for the major world regions throughout this period. Samaai et al. (2004) described three new species from the warm temperate south-east and east coasts of South Africa, from intertidal pools and deeper water locations. The aim of this contribution is to evaluate the status of nominal species of Strongylodesma, describe several new species from the Caribbean and Pacific regions, and correct several previous misidentifications. In doing so, we will clarify a framework for species recognition in the future.

\section{MATERIALS AND METHDDS}

The taxonomic revision was carried out by reassessment of original and more recent descriptions, and examination of type material and additional specimens loaned from various institutions, as well as recently collected specimens (by SCUBA), by light and scanning electron microscopy (SEM) (see Samaai \& Gibbons, 2005). Spicule dimensions are given as the mean length (range of length measurements) $\times$ mean width (range of width measurements) of 20 spicule measurements, unless otherwise stated. Abbreviations used in the text are as follows: MNHN (Muséum Nationale d'Histoire Naturelle, Paris); HBOM (Harbour Branch Oceanographic Museum, Florida); BMNH (The Natural History Museum, London); NIWA (National Institute of Water and Atmospheric Research, Wellington); MKB (personal collection of Dr M. Kelly); T.S. (personal reference number of T. Samaai); OCDN-specimen sample numbers for United States National Cancer Institute shallow-water collection programme contracted to the Coral Reef Research Foundation (CRRF). A complete collection of all OCDN sponge specimens is at CRRF and with M.K. Additionally, an un-catalogued collection is located at the Smithsonian Institution (United States National Museum).

The outline maps (Africa, South Africa and the east coast coastline) were created with Coastline Extractor (http:// www.ngdc.noaa.gov/mgg/shorelines/shorelines.html).

RESULTS

\footnotetext{
List of species described

Class DEMOSPONGIAE Sollas, 1885 Order POECILOSCLERIDA Topsent, 1928

Suborder LATRUNCULINA Kelly \& Samaai, 2002

Family LATRUNCULIIDAE Topsent, 1922

Genus Strongylodesma Lévi, 1969

Strongylodesma areolata Lévi, 1969

Strongylodesma algoaensis Samaai \& Kelly, 2003

Strongylodesma tsitsikammaensis Samaai \& Kelly, 2003

Strongylodesma aliwaliensis Samaai, 2004

Strongylodesma purpureus Samaai \& Kelly sp. nov.

Strongylodesma nigra Samaai \& Kelly sp. nov.

Strongylodesma novaecaledoniae Samaai \& Kelly sp. nov.

Strongylodesma tongaensis Samaai \& Kelly sp. nov.
}

\section{SYSTEMATICS}

Family LATRUNCULIIDAE Topsent, 1922

\section{DIAGNOSIS}

Massive hemispherical, pedunculate, or thinly encrusting sponges, with areolate porefields and raised fistular oscules; texture in life soft, slightly elastic, compressible, leathery in preservative. Colour in life typically liquorice brown, dark green, olive, brown or khaki, often tinged with forest-green or blue, or rarely pale beige to white. Structural megascleres are styles or anisostrongyles, rarely oxeas, these are frequently slightly irregular, sinuous, forming a compact tangential layer under the ectosome, and a wide-meshed reticulation in the choanosome that, in some genera, is bounded by broad dense ascending (Cyclacanthia Samaai, Govender \& Kelly), or chamber-forming tracts (Tsitsikamma Samaai \& Kelly). Microscleres are typically acanthose anisodiscorhabds, or 'chessman' spicules, or isospinodiscorhabds (Cyclacanthia Samaai, Govender \& Kelly), bearing various apical and basal whorls (manubrium) of discrete spines that merge to various degrees to form crenulate discs; the subsidiary and median whorls (in the upper half and midway along the shaft, respectively) are variously present, and form crenulate to spinose discs. Microscleres are typically arranged in a compact or irregular palisade of spicules orientated perpendicular to the ectosome, their bases buried in the ectosomal membrane. Viviparous. Shallow sublittoral to abyssal, polar to warm temperate (modified from Samaai \& Kelly, 2002).

\section{Genus Strongylodesma Lévi 1969}

\section{TYPE SPECIES}

Strongylodesma areolata Lévi, 1969: 959.

\section{SYNONYMY}

Strongylodesma areolata Lévi, 1969: 959, pl. 2, figure 4C; Samaai \& Kelly, 2002: 717, figure 5.

\section{DIAGNOSIS}

Spherical or hemispherical Latrunculiidae with elevated volcano-shaped or cylindrical oscules and fungiform or concave elliptical areolate porefields. Colour in life, brown to reddish brown. Choanosomal architecture consists of megascleres arranged in an irregular, large-meshed reticulation formed by wispy tracts of spicules, which lack spongin reinforcement. The ectosomal skeleton consists of a band of paratangential strongyles, the thickness of which differs considerably between species. The subectosomal skeleton is frequently a clear band of collagenous mesohyl, but may be unrecognizable as a distinct region in some species. Megascleres support the raised surface structures and may protrude beyond the surface. Megascleres are smooth, or terminally spined strongyles in one size category, some of which have a 'looped end' or 'shepherd's crook' malformation. Strongylodesma spp. contain pyrroloquinoline alkaloids such as batzellins, isobatzellins, discorhabdins and their derivatives (modified from Samaai \& Kelly, 2002).

Previous reviews. Samaai (2002); Samaai \& Kelly (2002); Samaai et al. (2003, 2004); Antunes et al. (2004, 2005) 
Strongylodesma areolata Lévi, 1969

(Figures 1A, 2A, 2B, 4; Table 1).

\section{TYPE SPECIES}

Strongylodesma areolata Lévi, 1969: 959, pl. 2, figure 4C.

Strongylodesma areolata Lévi, 1969: 959, pl. 2, figure 4c; Samaai \& Kelly, 2002: 717, figure 5.

A
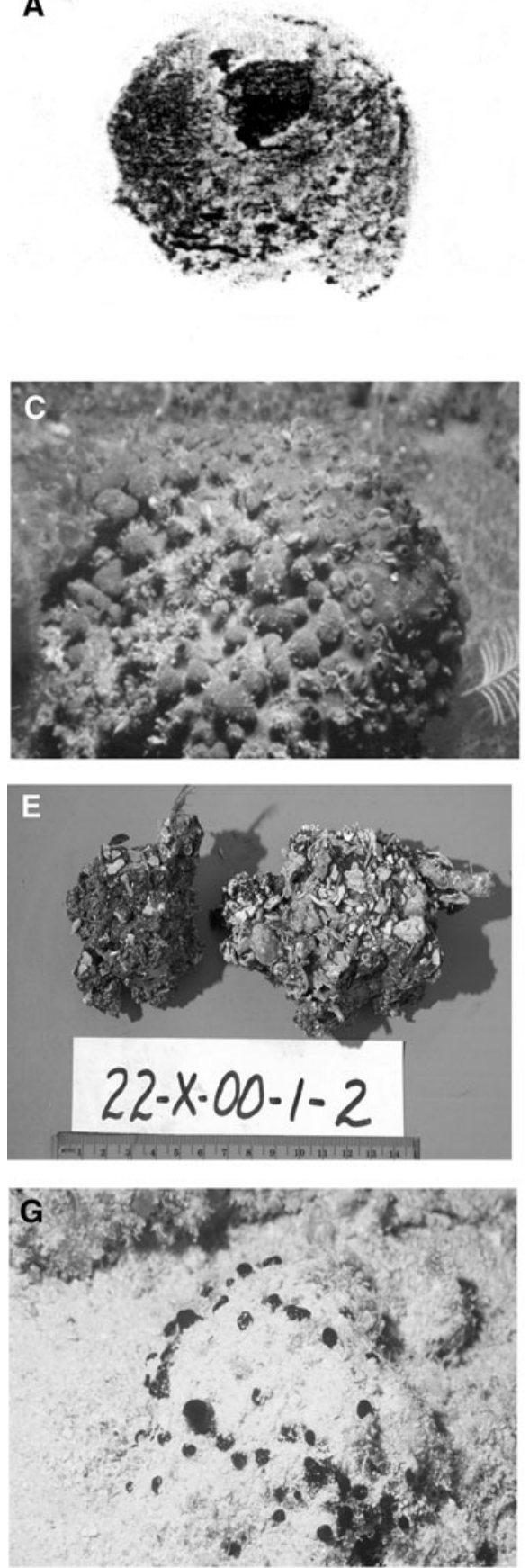

\section{MATERIAL}

Holotype: MNHN VEM 131 (DCL 1425), Strongylodesma areolata Lévi (1969), Vema Seamount, 1968.

DIAGNOSIS (MODIFIED FROM LÉVI, 1969)

Massive encrusting Latrunculiidae (Figure 1A), with smooth surface. Surface usually with membraneous fungiform oscules, together with flat circular or elliptical areolate porefields. Colour in life reddish-brown, beige in preservative. The texture of the sponge is firm and compressible.
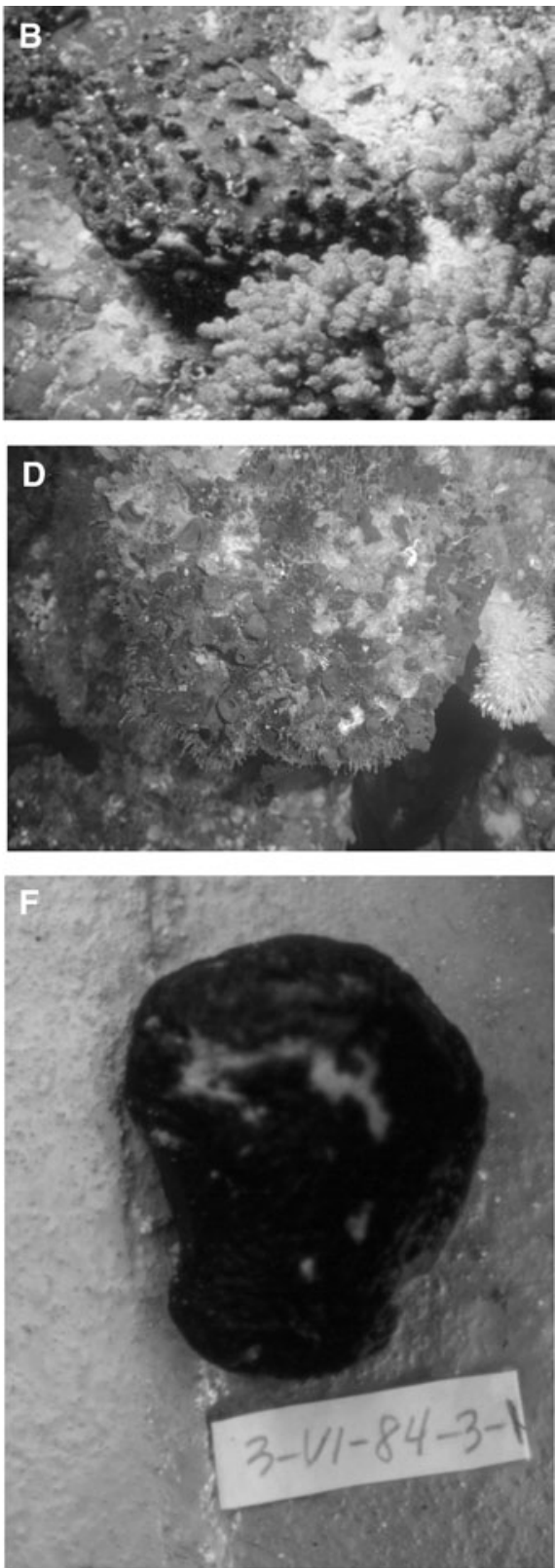

Fig. 1. Gross morphology of Strongylodesma spp: (A) Strongylodesma areolata Lévi, 1969 (reproduced from Lévi, 1969); (B) Strongylodesma algoaensis Samaai \& Kelly, 2003 (reproduced from Samaai et al., 2003); (C) Strongylodesma tsitsikammaensis Samaai \& Kelly, 2003 (reproduced from Samaai et al., 2003); (D) Strongylodesma aliwaliensis Samaai, 2004 (reproduced from Samaai et al., 2003, 2004); (E) Strongylodesma purpureus sp. nov. (picture from HBOI); (F) Strongylodesma nigra sp. nov. (picture from HBOI); (G) Strongylodesma tongaensis sp. nov. (picture from M. Kelly). 

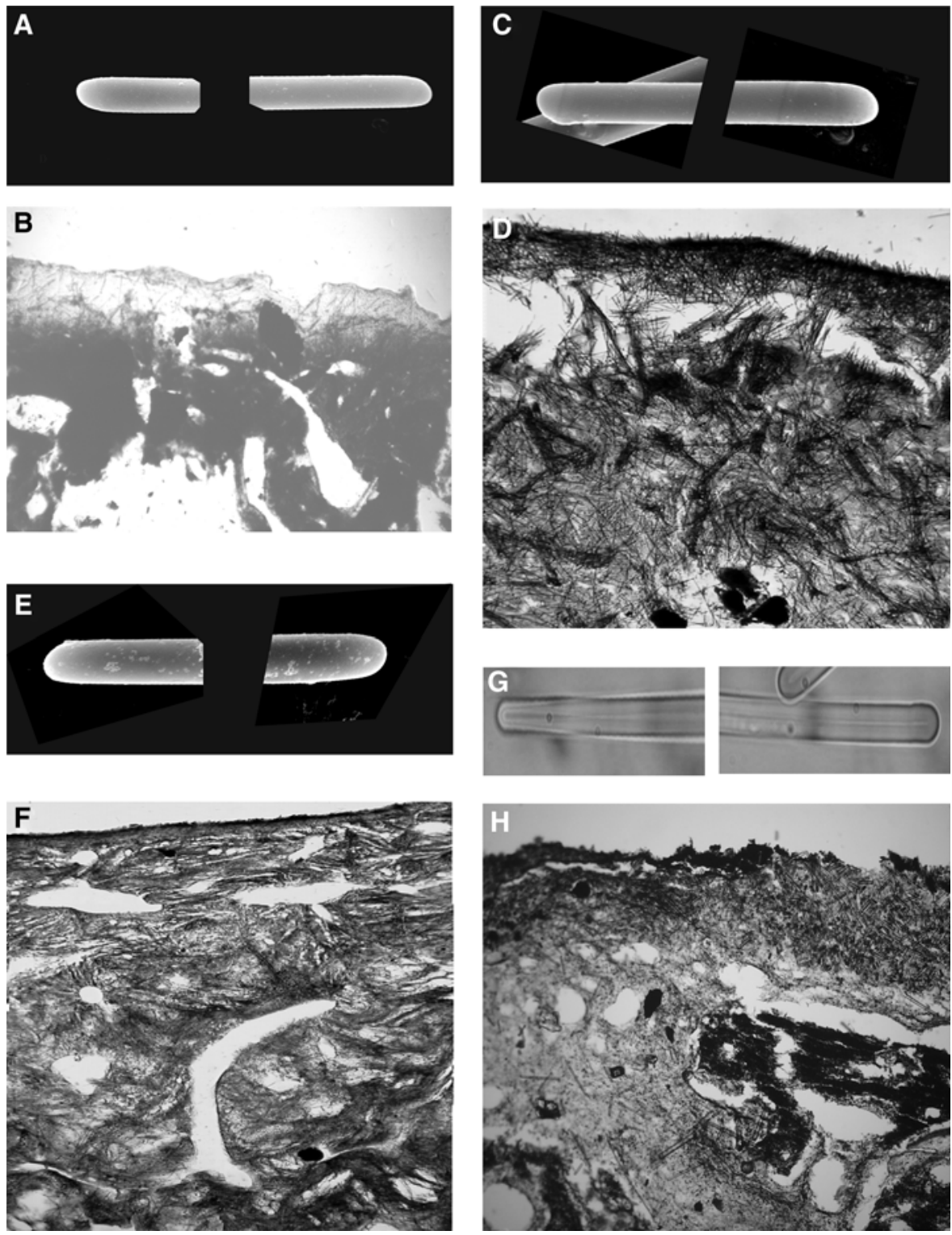

Fig. 2. Photomicrographs of megascleres and choanosomal architectures: (A\&B) Strongylodesma areolata Lévi, 1969 (reproduced from Lévi, 1969); (C\&D) Strongylodesma algoaensis Samaai \& Kelly, 2003 (reproduced from Samaai et al., 2003); (E\&F) Strongylodesma tsitsikammaensis Samaai \& Kelly, 2003 (reproduced from Samaai et al., 2003); (G\&H) Strongylodesma aliwaliensis Samaai, 2004 (reproduced from Samaai et al., 2004).

Megascleres are faintly terminally microspined strongyles, 299 $(282-319) \times 6 \quad(5-7) \mu \mathrm{m}, \quad \mathrm{N}=20$ (Figure $2 \mathrm{~A}$ ). The choanosomal architecture consists of an irregular polygonal-meshed reticulation of wispy tracts of faintly microspined strongyles (Figure $2 \mathrm{~B}$ ). These tracts range in width from 9-100 $\mu \mathrm{m}$ in thickness, forming meshes that are $120 \mu \mathrm{m}$ wide. The ectosomal skeleton consists of a clear thick band of collagenous mesohyal 227-270 $\mu \mathrm{m}$ thick, the base of which is lined with a thin band of paratengential strongyles (20 $\mu \mathrm{m}$ deep). Strongyles protrude beyond the surface in a haphazard manner. The sponge (whose habitat and depth is unknown), has only been recorded from the Vema Seamounts in the South Atlantic (Figure 4).

\section{GEOGRAPHICAL DISTRIBUTION}

Vema Seamount (South Atlantic) (Figure 4). The Vema Seamount is located at the following location; latitude $31^{\circ}$ $37.20^{\prime} \mathrm{S}$, longitude $8^{\circ} 20.40^{\prime} \mathrm{E}$.

\section{CHEMISTRY}

Unknown.

\section{REMARKS}

In the early 1960s, a collection of material from the Vema Seamount was sent to the Muséum National d'Histoire Naturelle, Paris, amongst which were several unidentified sponge species. In 1969, Lévi described and published the sponge collection, amongst which was a description of the first species of Strongylodesma. There are no verifiable records of $S$. areolata subsequent to its original description. Strongylodesma areolata was well described by Lévi (1969), who clearly differentiated it from Prianos, Hymeniacidon and Strongylacidon based on the skeletal architecture and strongyle megascleres. Species of Strongylodesma have strongyles as megascleres with a distinctive paratangential ectosomal layer, the thickness of this layer differing considerably between species, most of which have very thick layers. 
In Strongylodesma the ectosomal strongyles tend to be arranged peripherally perpendicular to the surface; this arrangement is assumed to be homologous to that of the erect layer of anisodiscorhabds of Latrunculia (Samaai \& Kelly, 2002; Samaai et al., 2003, 2004).

Strongylodesma areolata differs from S. algoaensis, S. tsitsikammaensis and $S$. aliwaliensis by the smaller size of the megascleres $((299(282-319) \times 6(5-7)$ um in the holotype MNHN VEM 131-DCL 1425)), and in the possession of terminally spined strongyles (as opposed to smooth strongyles in the South African species) (see Table 1). The subectosomal skeleton of $S$. areolata is a clear band of collagenous mesohyl $227-270 \mu \mathrm{m}$ thick, the base of which is a thin band of paratangential strongyles ( $20 \mu \mathrm{m}$ deep) (see Samaai, 2002; Samaai \& Kelly, 2002). This clear region is absent in South African Strongylodesma. The areolate porefields of $S$. areolata are flat and circular while those in the South African species are fungiform.

Strongylodesma algoaensis Samaai \& Kelly, 2003 (Figures 1B, 2C, 2D, 4; Table 1)

Strongylodesma algoaensis Samaai et al., 2003: 16, figures 3D, $5 \mathrm{E}, 6 \mathrm{D}$.

\section{MATERIAL}

Holotype: BMNH 1996.7.3.3: Algoa Bay, Port Elizabeth, South Africa, $33^{\circ} 50^{\prime} \mathrm{S} 25^{\circ} 45^{\prime} \mathrm{E}$, collected by P. Coetzee, University of Port Elizabeth, 15 April 1994, 15 m.

Paratype: SAM H-4964: Algoa Bay, Port Elizabeth, South Africa, $33^{\circ} 50^{\prime} \mathrm{S} 25^{\circ} 45^{\prime} \mathrm{E}$, collected by Dr P. Coetzee, University of Port Elizabeth, 15 April 1994, 15 m.

DIAGNOSIS (MODIFIED FROM SAMAAI ET AL., 2003) Massive spherical to hemispherical sponge (Figure $1 \mathrm{~B}$ ), with numerous large vase-shaped membranous oscules, and fungiform areolate porefields. Sand particles are present in the sponge surface. Colour in life, oak brown, in preservative, dark chocolate brown. The texture of the sponge is soft, compressible and fleshy. Megascleres are smooth anisostrongyles with a distinctive axial canal, $328(307-355) \times 9(7.2-9.6)$ $\mu \mathrm{m}$ (Figure $2 \mathrm{C}$ ). The choanosomal skeleton consists of an irregular polygonal-meshed reticulation of wispy tracts of anisostrongyles approximately $95-100 \mu \mathrm{m}$ thick (Figure $2 \mathrm{D}$ ). Towards the surface the tracts are perpendicular to the surface of the sponge, diverging just beneath the ectosome into fine plumose brushes $120-150 \mu \mathrm{m}$ thick. The subectosome is a loose feltwork of paratangential anisostrongyles approximately $120-200 \mu \mathrm{m}$ deep, above which these spicules become erect or oblique and pierce the surface. Anisostrongyles form a compact palisade around the opening of the papillae. The sponge was found in a moderately rugged rocky bottom habitat, with patches of sand between these rocks, together with coral and other sponges, at a depth of $15 \mathrm{~m}$.

GEOGRAPHICAL DISTRIBUTION

South Africa, Port Elizabeth (Figure 4).

\section{CHEMISTRY}

Contain biologically-active pyrroloquilonine alkaloids, discorhabdins $\mathrm{A}, \mathrm{D} \& \mathrm{H}$ and 3-dihydrodiscorhabdins (Antunes et al., 2004).
REMARKS (EMENDED FROM SAMAAI ET AL., 2003) Strongylodesma algoaensis differs from the genus holotype of the type species $S$. areolata Lévi by the larger size of the megascleres $((328(307-355) \times 9(7-9)$ um (see Table 1$))$, and in the possession of smooth strongyles (as opposed to faintly terminally spined strongyles in the holotype). This species is known so far only from the description of Samaai et al. (2003) and is one of three species described from South Africa. It is closest to S. tsitsikammaensis (Samaai et al., 2003), from which it differs in habitat, the latter found in intertidal rock pools and gullies and the former restricted to deeper waters on rocky platforms. The two species differ in coloration, S. algoaensis is brown while S. tsitsikammaensis is greenish brown. The oscules of $S$. algoaensis have no internal divisions as in $S$. tsitsikammaensis. The two species have quite different textures; S. algoaensis is fleshy and compressible while $S$. tsitsikammaensis is much firmer. This is reflected in the structure of the subectosomal region in both species; that of $S$. algoaensis is a loose feltwork of megascleres $120-200 \mu \mathrm{m}$ deep, whereas in the former species the subectosome is densely packed and $320 \mu \mathrm{m}$ deep.

Strongylodesma tsitsikammaensis Samaai \& Kelly, 2003 (Figures ${ }_{1} \mathrm{C}, 2 \mathrm{E}, \mathrm{F}, 4$; Table 1)

Strongylodesma tsitsikammaensis Samaai et al., 2003: 18, figures $3 \mathrm{E}, 5 \mathrm{~F}, 6 \mathrm{E}$.

\section{MATERIAL}

Holotype: BMNH 1996.7.3.5: Rheeders Bay, Tsitsikamma, South Africa, $34^{\circ} 10^{\prime} \mathrm{S} 23^{\circ} 54^{\prime} \mathrm{E}, 1.5 \mathrm{~m}$, collected by Dr P. Coetzee, University of Port Elizabeth, Dr M. Davis-Coleman, Rhodes University, 27 June 1996.

Paratype: SAM H-4965: Rheeders Bay, Tsitsikamma, South Africa, $34^{\circ} 10^{\prime} \mathrm{S} 23^{\circ} 54^{\prime} \mathrm{E}$, collected by Dr P. Coetzee, University of Port Elizabeth, Dr M. Davis-Coleman, Rhodes University, 27 June 1996, 1.5 m; SAM H-4966: Rheeders Bay, Tsitsikamma, South Africa, $34^{\circ} 10^{\prime} \mathrm{S} 23^{\circ} 54^{\prime} \mathrm{E}$, collected by Dr P. Coetzee, University of Port Elizabeth, Dr M. Davis-Coleman, Rhodes University 15 July 1996, 1.5 m; SAM H-4967: Algoa Bay, Port Elizabeth, South Africa, $33^{\circ} 50^{\prime} \mathrm{S} 25^{\circ}$ $45^{\prime}$ E, collected by Dr P. Coetzee, University of Port Elizabeth, 20 September 1996, 15 m; SAM H-4968: Rheeders bay, Tsitsikamma, $34^{\circ} 10^{\prime} \mathrm{S} 23^{\circ} 54^{\prime} \mathrm{E}$, collected by $\mathrm{Dr} \mathrm{M}$. Davis-Coleman, 15 October 1998, $1.5 \mathrm{~m}$; SAM H-4969: Rheeders Bay, Tsitsikamma, South Africa, $34^{\circ} 10^{\prime} \mathrm{S} 23^{\circ} 54^{\prime} \mathrm{E}$, collected by Dr M. Davis-Coleman, Rhodes University, 15 October 1998, 1.5 m; SAM H-4970: Rheeders bay, Tsitsikamma, $34^{\circ} 10^{\prime} \mathrm{S}$ $23^{\circ} 54^{\prime} \mathrm{E}$, intertidal rock pools, depth $2 \mathrm{~m}$, collected by $\mathrm{M}$. Davis-Coleman, Rhodes University, 5 April 1999.

DIAGNOSIS (MODIFIED FROM SAMAAI ET AL., 2003) Massive semispherical sponge (Figure $1 \mathrm{C}$ ), with numerous, randomly scattered cylindrical or volcano-shaped, thin-lipped oscules, having internal dividing membranes. The areolate porefields are smooth and fungiform. Sand particles sometimes present on the surface of the sponge. Colour in life greenishbrown, interior brown; in preservative dark leather brown. The texture of the sponge is resilient, but slightly compressible. Megascleres are smooth anisostrongyles, $348(307-403) \times 7.32$ (7.2-9.6) $\mu \mathrm{m}$ (Figure $2 \mathrm{E}$ ). The choanosomal skeleton consists of a dense, meandering, irregular reticulation of wispy tracts of megascleres approximately $80-100 \mu \mathrm{m}$ thick (Figure $2 \mathrm{~F}$ ). 
Table 1. Review of Strongylodesma species worldwide, including new material examined.

\begin{tabular}{|c|c|c|c|c|c|c|c|c|c|c|}
\hline Genus/species & Authority & $\begin{array}{l}\text { Reference } \\
\text { number }\end{array}$ & $\begin{array}{l}\text { Previous } \\
\text { designation }\end{array}$ & $\begin{array}{l}\text { By } \\
\text { whom } \\
\text { designated }\end{array}$ & Locality & $\begin{array}{l}\text { Spicule } \\
\text { dimensions }\end{array}$ & $\begin{array}{l}\text { Gross } \\
\text { morphology }\end{array}$ & $\begin{array}{l}\text { Colour in } \\
\text { life }\end{array}$ & Strongyle type & Chemistry \\
\hline $\begin{array}{l}\text { Strongylodesma } \\
\text { areolata } \\
\text { (holotype) }\end{array}$ & $\begin{array}{l}\text { Lévi, } 1969 \\
\quad \text { (rediscribed } \\
\text { in Samaai \& } \\
\text { Kelly, 2002) }\end{array}$ & $\begin{array}{l}\text { VEM } 131(\mathrm{DCL} \\
1425)\end{array}$ & $\begin{array}{l}\text { Strongylodesma } \\
\text { areolata }\end{array}$ & Lévi, 1969 & $\begin{array}{l}\text { Vema } \\
\text { Seamount, } \\
\text { South } \\
\text { Atlantic }\end{array}$ & $\begin{array}{l}299(282-319) \\
\times 6(5-7) \\
\mu \mathrm{m}\end{array}$ & $\begin{array}{l}\text { Massive } \\
\quad \text { encrusting }\end{array}$ & Reddish-brown & $\begin{array}{l}\text { Faintly terminally } \\
\text { micropined }\end{array}$ & Unknown \\
\hline $\begin{array}{l}\text { Strongylodesma } \\
\text { algoaensis }\end{array}$ & $\begin{array}{l}\text { Samaai \& Kelly, } \\
\quad 2003\end{array}$ & BMNH 1996.7.3.3 & & $\begin{array}{l}\text { Samaai \& } \\
\text { Kelly }\end{array}$ & $\begin{array}{l}\text { Algoa Bay, } \\
\text { South Africa }\end{array}$ & $\begin{array}{l}328(307-355) \\
\times 9(7.2- \\
9.6) \mu \mathrm{m}\end{array}$ & Massive spherical & Oak brown & Smooth & $\begin{array}{l}\text { Discorhabdins } \\
\text { A, D \& H; } 3^{-} \\
\text {dihydrodiscorhabdins }\end{array}$ \\
\hline $\begin{array}{l}\text { Strongylodesma } \\
\quad \text { tsitsikammaensis }\end{array}$ & $\begin{array}{l}\text { Samaai \& } \\
\text { Kelly, } 2003\end{array}$ & BMNH 1996.7.3.5 & & $\begin{array}{l}\text { Samaai \& } \\
\text { Kelly }\end{array}$ & $\begin{array}{l}\text { Tsitsikamma, } \\
\text { South Africa }\end{array}$ & $\begin{array}{l}348(307-403) \\
\times 7.32(7.2- \\
9.6) \mu \mathrm{m}\end{array}$ & $\begin{array}{l}\text { Massive } \\
\text { semispherical }\end{array}$ & Greenish brown & Smooth & Unknown \\
\hline $\begin{array}{l}\text { Strongylodesma } \\
\text { aliwaliensis }\end{array}$ & Samaai, 2004 & SAM H-5083 & & & $\begin{array}{l}\text { Aliwal } \\
\text { Shaol, } \\
\text { South Africa }\end{array}$ & $\begin{array}{l}428(235-590) \\
\times 7(4-9) \\
\mu \mathrm{m}\end{array}$ & $\begin{array}{l}\text { Massive } \\
\text { semispherical }\end{array}$ & Olive green & Smooth & Makaluvamine I \\
\hline \multirow[t]{2}{*}{ S. purpureus } & sp. nov. & $\begin{array}{l}\mathrm{HBOM} \\
\quad 003: 00922\end{array}$ & Batzella sp. & $\begin{array}{l}\text { Van Soest et al., } \\
1996\end{array}$ & $\begin{array}{l}\text { Bahamas } \\
\quad \text { (Caribbean) }\end{array}$ & $\begin{array}{l}276.5(250- \\
290) \times 4.8 \\
(4.8) \mu \mathrm{m}\end{array}$ & Encrusting & Purple brown & $\begin{array}{l}\text { Smooth } \\
\quad \text { (malformed) }\end{array}$ & Discorhabdins S, T \& U \\
\hline & & $\begin{array}{l}\mathrm{HBOM} \\
\quad \text { oo3:00983 }\end{array}$ & Batzella sp. & Gunasekera & $\begin{array}{l}\text { Bahamas } \\
\text { (Caribbean) }\end{array}$ & & & & & \\
\hline \multirow[t]{2}{*}{$\begin{array}{l}\text { Strongylodesma } \\
\text { nigra }\end{array}$} & sp. nov. & $\begin{array}{l}\mathrm{HBOM} \\
\quad 003: 00050\end{array}$ & Batzella sp. & $\begin{array}{l}\text { Van Soest } \\
\text { et al., } \\
1996\end{array}$ & $\begin{array}{l}\text { Bahamas } \\
\quad \text { (Caribbean) }\end{array}$ & $\begin{array}{l}331.5(270- \\
350) \times 2.4 \\
(2.4) \mu \mathrm{m}\end{array}$ & Encrusting & Black & Microspined & $\begin{array}{l}\text { Batzellins A \& C; } \\
\quad \text { Isobatzellins A-D }\end{array}$ \\
\hline & & $\begin{array}{l}\mathrm{HBOM} \\
\text { o03:00051 }\end{array}$ & Batzella sp. & $\begin{array}{l}\text { Van Soest } \\
\text { et al., } \\
1996\end{array}$ & $\begin{array}{l}\text { Bahamas } \\
\quad \text { (Caribbean) }\end{array}$ & $310.5(260-350)$ & $\times 4.8(2.4) \mu \mathrm{m}$ & & & \\
\hline \multirow[t]{2}{*}{$\begin{array}{l}\text { Strongylodesma } \\
\text { novaecaledoniae }\end{array}$} & sp. nov. & Ts 10 & $\begin{array}{l}\text { Strongylodesma } \\
\text { sp. }\end{array}$ & $\begin{array}{l}\text { Similar to } \\
\text { Levi, } \\
1998, \\
\text { p. } 121\end{array}$ & New Caledonia & $\begin{array}{l}302(268-317) \\
\times 4.8(4.8) \\
\mu \mathrm{m}\end{array}$ & $\begin{array}{l}\text { Massive } \\
\quad \text { semispherical }\end{array}$ & Brown & Smooth & Unknown \\
\hline & & TS 12 & $\begin{array}{l}\text { Strongylodesma } \\
\text { sp. }\end{array}$ & Levi, 1998 & New Caledonia & $299(278-326) \times$ & $4.8(4.8) \mu \mathrm{m}$ & & & \\
\hline $\begin{array}{l}\text { Strongylodesma } \\
\text { tongaensis }\end{array}$ & sp. nov. & OCDN $5532-\mathrm{W}$ & Strongylodesma sp & & Tonga & $\begin{array}{l}294.5(260- \\
\quad 330) \times 2.4 \\
(2.4) \mu \mathrm{m}\end{array}$ & Encrusting & Dark green & Smooth & Unknown \\
\hline
\end{tabular}



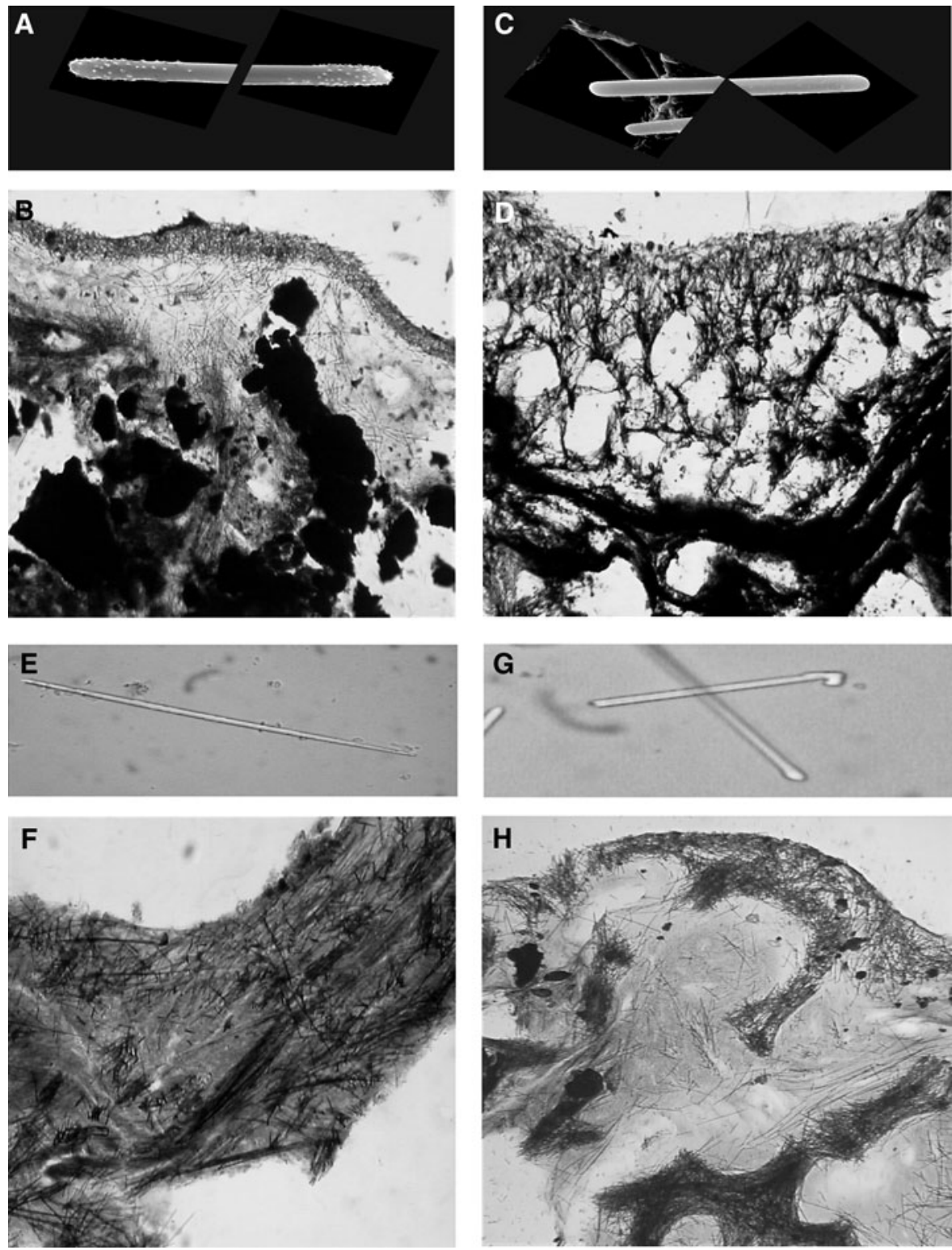

Fig. 3. Photomicrographs of megascleres and choanosomal architectures: (A\&B) Strongylodesma purpureus sp. nov.; (C\&D) Strongylodesma nigra sp. nov.; (E\&F) Strongylodesma novaecaledoniae sp. nov.; (G\&H) Strongylodesma tongaensis sp. nov.

In the deeper choanosome the tracts are ill-defined but diverge towards the surface where they become more robust and plumose, tracts now $200-250 \mu \mathrm{m}$ wide. Interstitial megascleres are common. The subectosome is a dense paratangential feltwork of anisostrongyles approximately $320 \mu \mathrm{m}$ deep; these protrude beyond the surface in a haphazard manner. The sponge is found in intertidal rock pools and sand-filled gullies, associated with bryozoa, algae, hard coral and other sponges, at a depth of between 1.5-2.0 m. In deeper waters off Algoa Bay the sponge is found on moderately rugged rocky bottom, with patches of sand between rocks, together with coral and other sponge at a depth of $15 \mathrm{~m}$.

\section{GEOGRAPHICAL DISTRIBUTION}

South Africa (Tsitsikamma and Port Elizabeth) (Figure 4).

\section{REMARKS}

Strongylodesma tsitsikammaensis is very similar to species of Latrunculia in the field, with areolate porefields and typical greenish-brown coloration. This species differs from others in its firm but compressible texture, habitat, thin-lipped volcano shaped oscules with internal membranes and fairly large smooth anisostyles (see Table 1 ). It is superficially very similar to $S$. algoaensis in being semispherical and having a brownish external coloration when alive, with numerous areolate porefields.

Strongylodesma aliwaliensis Samaai, 2004

(Figures $1 \mathrm{D}, 2 \mathrm{G}, 2 \mathrm{H}, 4$; Table 1 )

Strongylodesma aliwaliensis Samaai et al., 2004: 1-11, figures $2 \mathrm{~A}, \mathrm{~B}, \mathrm{C} ; 3 \mathrm{~A}, \mathrm{~B}, \mathrm{C}, \mathrm{D}$.

MATERIAL

Holotype: SAM H-5083 (cross reference TS 970): Umkomaas, Aliwal Shoal, east coast of South Africa, $30^{\circ} 26^{\prime} 202^{\prime \prime} S 32^{\circ}$ 


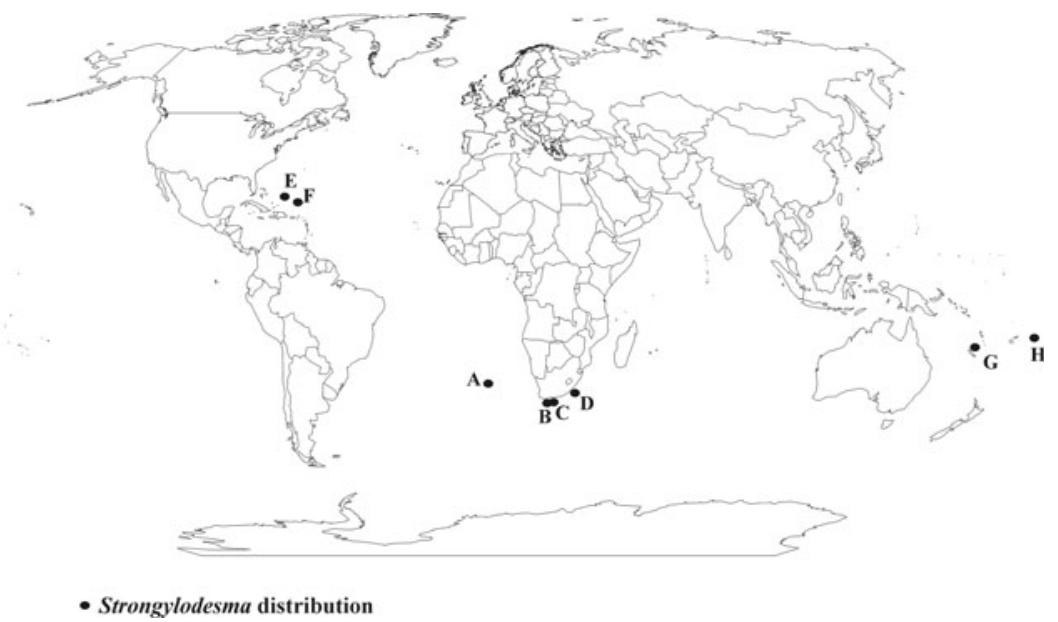

Fig. 4. Worldwide distributions of all valid species of Strongylodesma. Distributions of (A) Strongylodesma areolata Lévi, 1969; (B) Strongylodesma algoaensis Samaai \& Kelly, 2003; (C) Strongylodesma tsitsikammaensis Samaai \& Kelly, 2003; (D) Strongylodesma aliwaliensis Samaai 2004; (E) Strongylodesma purpureus sp. nov.; (F) Strongylodesma nigra sp. nov.; (G) Strongylodesma novaecaledoniae sp. nov.; (H) Strongylodesma tongaensis sp. nov.

$02^{\prime} 558^{\prime \prime}$ E, collected by Toufiek Samaai and Vic Peddemors, 4 September 2003, at a depth of $18 \mathrm{~m}$.

Paratype: SAF 94-23: Umkomaas, Aliwal Shoal, east coast of South Africa, $30^{\circ} 26^{\prime} 202^{\prime \prime} \mathrm{S} 32^{\circ} \mathrm{O}^{\prime} 558^{\prime \prime} \mathrm{E}$, collected by Greg Hooper, 21 June 1994, at a depth of $18 \mathrm{~m}$. TS VG 1: Umkomaas, Aliwal Shoal (Raggie Cave and Anvil Rock), east coast of South Africa, $30^{\circ} 26^{\prime} 202^{\prime \prime} \mathrm{S} 32^{\circ} \mathrm{O}^{\prime} 558^{\prime \prime} \mathrm{E}$, collected by Toufiek Samaai, 1 May 2004, at a depth of $15 \mathrm{~m}$.

DIAGNOSIS (MODIFIED FROM SAMAAI ET AL., 2004) Massive, hemispherical sponge (Figure $1 \mathrm{D}$ ), sometimes thickly encrusting with an ectosomal layer not easily separable from the underlying choanosomal tissue, approximately $1 \mathrm{~mm}$ thick. The surface of the sponge is smooth with numerous, randomly scattered cylindrical or volcano-shaped oscules, with no internal canal divisions, and smooth mushroom-like areolate porefields. Sand particles and other epifauna (hydroids and red algae) present on the surface and within the choanosomal tissue of the sponge. Colour in life dark olive green; in preservative dark oily brown/black. The texture of the sponge is soft and compressible. Megascleres are smooth strongyles, with one end narrower than the other, $428(235-590) \times 7(4-9) \mu \mathrm{m}, \mathrm{N}=20$ (Figure $2 \mathrm{G}$ ). The choanosome is divided into 'honey-comb like' chambers and convoluted layers by very thick reinforced tracts of strongyles, these tracts range in width $100-294 \mu \mathrm{m}$ thick (paratype 200-490 $\mu \mathrm{m}$ thick) (Figure $2 \mathrm{H}$ ). These convoluted layers are a dense paratangential feltwork of strongyles, similar to that found in the ectosome, suggesting that these convoluted layers may represent an early ectosomal surface. Within and between the 'honey-comb like' chambers and convoluted layers the choanosome is much softer, containing the skeleton that consists of an ill-formed, irregular reticulation of strongyles, these tracts range in width from $50-100 \mu \mathrm{m}$, with no distinction between the primary and secondary tracts. Towards the centre of the choanosome the tracts are more confused and ill-defined, and towards the surface they become more robust and vertically arranged and radiate to form plumose tracts $200 \mu \mathrm{m}$ wide. Scattered throughout the choanosome, between the tracts, are a few interstitial megascleres in the same category as the main spicules. The ectosome is composed of a dense irregular interlocking paratangential feltwork of strongyles approximately 200$350 \mu \mathrm{m}$ deep. Below this interlocking paratangential layer a clear band of collagenous mesohyl is present. Strongyles do not protrude beyond the surface. The sponge is found on the shallow reef platform of Aliwal shoal, at a depth of $18 \mathrm{~m}$ and on the vertical surfaces on the outside of a cave and boulder at a depth of $15 \mathrm{~m}$. This species is very rare and is found in areas were there is current flow.

\section{GEOGRAPHICAL DISTRIBUTION}

South Africa (Umkomaas) (Figure 4).

\section{CHEMISTRY}

Preliminary chemical analysis (Keyzers et al., 2004) of sponge extracts has confirmed the presence of several pyrroloiminoquinone products, for example makaluvamine I.

REMARKS (TAKEN FROM SAMAAI ET AL., 2004)

A variety of specimens were seen in the field, but they were all allopatric in their distribution at the type locality. Specimens of $S$. aliwaliensis are found on the same habitat type as described for $S$. algoaensis (both are restricted to deeper waters on rocky platforms), but differs from it in that the former is found in subtropical waters on the east coast and the latter in the warm temperate waters on the south-east coast of Algoa Bay (South Africa). Strongylodesma tsitsikammaensis on the other hand is restricted to the intertidal rock pools and gullies in the Tsitsikamma National Park region. Strongylodesma aliwaliensis also differ from the two known South African species in coloration; S. tsitsikammaensis is greenish brown while $S$. algoaensis is brown, whereas the new species is a dark olive green colour. Strongylodesma aliwaliensis also differs from S. tsitsikammaensis and S. algoaensis in having much larger megascleres ( $(S$. tsitsikammaensis $348 \quad(307-403) \times 7.32$ $(7.2-9.6) \mu \mathrm{m} ; S$. algoaensis $328(307-355) \times 9(7.2-9.6)$ $\mu \mathrm{m})$ ), and in that the strongyles taper off or become narrow on one side, a character not previously recorded in the strongyles of Strongylodesma.

The ectosome also differ in the structure of the paratangential layer between the three South African species; in S. algoaensis the ectosome is composed of a loose feltwork 
of paratangential strongyles; in S. tsitsikammaensis and $S$. algoaensis the ectosome is dense and interlocking differing only in the presence of a clear subectosomal mesohyl layer in S. algoaensis. Strongylodesma aliwaliensis is very similar to species of Latrunculia in the field, with areolate porefields, a soft, inflated, compressible texture, and a typical dark pigmentation. It is only at the histological level that the genus and this species are distinguishable, by a lack of microscleres.

Strongylodesma purpureus Samaai \& Kelly sp. nov. (Figures $1 \mathrm{E}, 3 \mathrm{~A}, 3 \mathrm{~B}, 4$; Table 1)

Van Soest et al., 1996: 95, figure 3; Batzella sp. Gunasekera et al., 1999: 174; Gunasekera et al., 2003: 1616.

\section{MATERIAL}

Holotype: HBOM 003:00922 ((HBOI 24-VIII-94-3-001 (cross reference Ts 40)), Bahamas, Great Bahama Bank, west of Riding Rock, $25^{\circ} 15.562^{\prime \prime} \mathrm{N} 79^{\circ} 11.109^{\prime \prime} \mathrm{W}$, depth $141 \mathrm{~m}$, collected by S. Pomponi, 27 August 1994.

Paratype: HBOM 003:00983 (HBOI 22-X-00-1-002), Ocean Cay, approximately 20 nautical miles south of Bimini, Bahamas, $25^{\circ} 23.93^{\prime} \mathrm{N} 79^{\circ} 14.37^{\prime} \mathrm{W}$, depth $141 \mathrm{~m}$, collected by manned submersible (JSL I-4272), 22 October 2000.

\section{DESCRIPTION}

Thickly encrusting sponge following contours of substrata (Figure $1 \mathrm{E}$ ), up to $2.5 \mathrm{~cm}$ high and $3.5 \mathrm{~cm}$ wide. Texture soft, compressible, fleshy. Surface smooth, with numerous scattered large cylindrical membranous oscules, $5 \mathrm{~mm} \times$ $10 \mathrm{~mm}$ wide and high, and fungiform areolate porefields $1 \mathrm{~mm}$ high and $8 \mathrm{~mm}$ wide. Sand particles are present especially within the choanosome of the sponge. Colour in life purple brown; in preservative brown. Ectosome very thin and membranous, and readily separable from underlying choanosome.

\section{SPICULES}

Megascleres. Acanthostrongyles: Isodiametric with equally shaped apices but spicules are curved in centre, making it bow shaped. A few malformed 'shepherd's crook' strongyles occur. Under SEM strongyles show a strong apical microspination, $276.5 \quad(250-290) \mu \mathrm{m} \times 4.8 \quad(4.8) \mu \mathrm{m}, \quad \mathrm{N}=20$ (Figure 3A).

\section{SKELETON}

Choanosomal architecture consists of an irregular polygonalmeshed reticulation of wispy tracts of strongly microspined strongyles (Figure $3 \mathrm{~B}$ ), ranging in width from $50-100 \mu \mathrm{m}$, forming meshes $90 \mu \mathrm{m}$ wide, sometimes being irregular or triangular towards the subectosomal region. Within the subectosomal region, spicule orientation is confused and sparse creating a thick band of collagenous mesohyal $300-500 \mu \mathrm{m}$ thick, above which is lined with a thin band of paratangential strongyles (20 $\mu \mathrm{m}$ deep). In some places towards the surface the tracts are perpendicular, diverging just beneath ectosome into fine plumose brushes, $100-130 \mu \mathrm{m}$ thick. The ectosome is composed of a thin dense feltwork of tangential to paratangential lying strongyles approximately $100-200 \mu \mathrm{m}$ deep, above which is a sparse disorganized layer of erect or oblique strongyles that pierce the surface.
SUBSTRATE, DEPTH RANGE AND ECOLOGY

Found on rubble rocky slope, with patches of sand between rocks, at a depth of $133 \mathrm{~m}$. Sponges are quite abundant in this region. The sponge incorporates sediment (Halimeda plates) into its skeleton.

\section{GEOGRAPHICAL DISTRIBUTION \\ Caribbean (Figure 4).}

\section{ETYMOLOGY}

Named for the purple coloration of this species, purpureus (L.).

\section{CHEMISTRY}

Gunasekera et al. (1999) reported discorhabdin P from sample HBOI 24-VIII-94-3-001, whilst Gunasekera et al. (2003) reported pyrroloiminoquinone alkaloids (discorhabdins $\mathrm{S}, \mathrm{T}$, and $\mathrm{U}$ ) from sample HBOI 22-X-00-1-002.

\section{REMARKS}

Van Soest (1996) provisionally identified several specimens of S. purpureus sp. nov. as Batzella sp. (Poecilosclerida: Chondropsidae), noting the presence of curious malformed 'shepherd's crook' strongyles seen in Batzella rosea from Curaçao (Van Soest 1984). Thus, many sponges with 'shepherd's crook' strongyles were assigned to Batzella in the marine natural products literature in particular (Pomponi in Sakemi et al., 1989; Sun et al., 1990; Gunasekera et al., 1999, 2003), despite their uncharacteristically dark coloration and areolate surface structures. A recent revision of the status of Batzella confirms that it has the skeletal characteristics (plumose columns of strongyles) of other Chondropsidae (Van Soest, 2002) and thus is clearly separate from Strongylodesma as recognized here.

The discovery of pyrroloiminoquinone alkaloids and discorhabdins in the type material of $S$. purpureus sp. nov. (Gunasekera et al., 1999, 2003) raises the possibility that these Caribbean specimens are more closely related to Strongylodesma, despite the presence of malformed strongyles. Coupled with the oily dark purple-brown coloration, thickly encrusting morphology, and areolate surface structures, the chemistry identified from this species strongly links these specimens with species of Strongylodesma, which are known to contain discorhabdins and their derivatives (Samaai \& Kelly, 2002; Samaai et al., 2003, 2004; Antunes et al., 2004; Keyzers et al., 2004), and the Latrunculiidae in general (Samaai \& Kelly, 2002; Antunes et al., 2005).

Strongylodesma nigra Samaai \& Kelly sp. nov.

(Figures $1 \mathrm{~F},{ }_{3} \mathrm{C}, 3 \mathrm{D}, 4$; Table 1 )

Batzella sp. Sakemi et al., 1989: Sun et al., 1990: 4964; Van Soest et al., 1996: 95, figure 3.

\section{MATERIAL}

Holotype: HBOM 003:00051 ((sample ID-14-XI-87-3-005 (cross reference Ts 38a)). Bahamas, Great Bahama Bank, west end, $26^{\circ} 41^{\prime} 67^{\prime \prime} \mathrm{N} 79^{\circ}$ oo $60^{\prime \prime} \mathrm{W}$, depth $125 \mathrm{~m}$, collected by E. Armstrong, 12 August 1990.

Paratype: HBOM 003:00050 ((sample ID-3-VI-84-3-001 (cross reference Ts 35)). Bahamas, Great Bahama Bank, between Lucaya and Freetown, $26^{\circ} 32^{\prime} 3^{\prime \prime} \mathrm{N} 78^{\circ} 30^{\prime} 09^{\prime \prime} \mathrm{W}$, depth $118 \mathrm{~m}$, collected by E. Armstrong, 1 August 1990. 


\section{DESCRIPTION}

Small, amorphous sponge (Figure $1 \mathrm{~F}$ ). Available voucher fragments are about $1 \mathrm{~cm}$ in thickness. Surface smooth, with no apparent oscules or areolate porefields visible. Texture compressible, but firm. Colour in life black; in preservative tan. Ectosome very thin, and readily separable from underlying choanosome.

\section{SPICULES}

Megascleres. Microspined strongyles: Isodiametric with equally shaped apices. A few malformed shepherd's crook' strongyles occur. Under SEM strongyles show a faint apical microspination, $331.5(270-350) \mu \mathrm{m} \times 2.4(2.4) \mu \mathrm{m}, \mathrm{N}=$ 20 (Figure ${ }_{3} \mathrm{C}$ ).

\section{SKELETON}

Choanosomal architecture consists of an irregular vague polygonal-meshed reticulation of wispy tracts of faintly microspined strongyles (Figure $3 \mathrm{D}$ ). These tracts range in width from 50-60 $\mu \mathrm{m}$ in thickness, forming very ill-formed meshes. Towards the surface the tracts are perpendicular, diverging just beneath ectosome into fine plumose brushes, $100 \mu \mathrm{m}$ thick. The ectosome is composed of a thin feltwork of tangential to paratangential lying strongyles approximately $70 \mu \mathrm{m}$ deep. In some places this layer may be $400 \mu \mathrm{m}$ deep, or, spicule orientations may be confused and sparse creating a band of collagenous mesohyal $50-100 \mu \mathrm{m}$ thick. The surface is pierced by a sparse disorganized layer of erect or oblique strongyles.

\section{SUBSTRATE, DEPTH RANGE AND ECOLOGY}

The holotype was found on a rocky wall at a depth of $125 \mathrm{~m}$ and specimen HBOM 003:00051a was found on a rocky slope, with patches of sand between rocks, at a depth of $118 \mathrm{~m}$. Depth range $118-125 \mathrm{~m}$.

\section{GEOGRAPHICAL DISTRIBUTION}

Caribbean (Figure 4).

\section{ETYMOLOGY}

Named for the black coloration of the sponge, nigra (L.)

\section{CHEMISTRY}

According to Sakemi et al. (1989), Sun et al. (1990) and Van Soest et al. (1996), this sponge contains pyrroloquinoline alkaloids (batzellins $\mathrm{A}-\mathrm{C}(2 \mathrm{O}-22)$ and isobatzellins $\mathrm{A}-\mathrm{D}$ $(23-26))$.

\section{REMARKS}

Strongylodesma nigra sp. nov. was originally described by Van Soest et al. (1996) as a species of Batzella (Poecilosclerida: Chondropsiidae), yet as for $S$. purpureus sp. nov., the chemical, morphological and coloration characteristics suggest strong affinity with Latrunculiidae in general and Strongylodesma in particular. Strongylodesma nigra sp. nov. differ from $S$. purpureus sp. nov. by the smaller size of the megascleres (Table 1) that are also faintly apical microspined. The two species differ in coloration, $S$. nigra sp. nov. is black while $S$. purpureus sp. nov is purple brown. The two species have quite different textures; $S$. purpureus sp. nov. is fleshy and compressible while $S$. niger sp. nov. is much firmer.
Strongylodesma novaecaledoniae Samaai \& Kelly sp. nov.

(Figures ${ }_{3} \mathrm{E},{ }_{3} \mathrm{~F}, 4$; Table 1)

Strongylodesma sp. Lévi, 1998: p. 121.

\section{MATERIAL}

Holotype: BMNH 2008.5.2.3 (cross reference TS 10, MKB 722). Nouméa, New Caledonia, $33^{\circ} 50^{\prime} \mathrm{S} 25^{\circ} 45^{\prime} \mathrm{E}$, depth 15 m, Ex ORSTOM collection, Nouméa, 1991.

Paratype: BMNH.2008.5.2.2 (cross reference TS 12, MKB 724). Nouméa, New Caledonia, $33^{\circ} 50^{\prime} \mathrm{S} 25^{\circ} 45^{\prime} \mathrm{E}$, depth 15 m, Ex ORSTOM collection, Nouméa 1991.

\section{DESCRIPTION}

Massive hemispherical to spherical sponge, up to $8 \mathrm{~cm}$ in diameter and $6 \mathrm{~cm}$ high. Texture is highly compressible and soft in life, but tough and non-compressible in preservative. Surface smooth, with irregular distributed and slightly elevated cylindrical membranous oscules, $1-2 \mathrm{~cm}$ diameter, encircled by small fungiform or mushroom-like areolate porefields, $0.5 \mathrm{~mm}$ high and $2-3 \mathrm{~mm}$ wide. Sand particles are present, concentrated on the sides of the sponge. Colour in life light chocolate brown, in ethanol, dark chocolate brown. Ectosome not readily separable from underlying choanosome.

\section{SPICULES}

Megascleres. Anisostrongyles: smooth, thin long, with unequally shaped apices, one end somewhat round, the other tapering gradually, $302(268-317) \mu \mathrm{m} \times 4.8(4.8) \mu \mathrm{m}$, $\mathrm{N}=20$ (Figure $\left.{ }_{3} \mathrm{E}\right)$.

\section{SKELETON}

The choanosomal architecture consists of an irregular polygonal-meshed reticulation of wispy tracts of strongyles approximately $50-90 \mu \mathrm{m}$ thick (Figure $3 \mathrm{~F}$ ). Towards the subectosome tracts become more triangular and diverge in a perpendicular manner just beneath the ectosome into fine plumose brushes $90-130 \mu \mathrm{m}$ thick. The ectosome is composed of a thin loose feltwork of paratangential strongyles approximately $30 \mu \mathrm{m}$ deep, above which is a sparse disorganized layer of erect or oblique strongyles that pierce the surface. Interstitial spicules are abundant throughout the choanosome.

\section{SUBSTRATE, DEPTH RANGE AND ECOLOGY}

The specimens were collected by SCUBA by M.K. on 25 September 1990 at Isle Maître, Nouméa, New Caledonia, at a depth of $12 \mathrm{~m}$. The habitat was coral rubble, sand and seagrass flat between coral heads. This species is also associated with lagoonal sand flats and Halimeda beds and are found at depths of 10-30 m (Hooper \& Battershill, 1998).

\section{GEOGRAPHICAL DISTRIBUTION}

New Caledonia (Figure 4).

\section{ETYMOLOGY}

Named after the type locality.

\section{CHEMISTRY}

Unknown. 


\section{REMARKS}

Strongylodesma novaecaledoniae sp. nov. was first identified by Hooper \& Battershill in Lévi (1998: 121) but was never fully described. It is highly characteristic in life with the almost spherical morphology and beautiful light chocolate brown coloration in life. Strongylodesma novaecaledoniae sp. nov. differs from $S$. areolata Lévi in several ways; it has much longer and slimmer strongyles, it differs in the thickness and structure of the ectosomal paratangential layer, and the megascleres are smooth compared to being slightly spined.

Strongylodesma tongaensis Samaai \& Kelly sp. nov. (Figures $1 \mathrm{G}, 3 \mathrm{G}, 3 \mathrm{H}, 4$; Table 1 )

\section{MATERIAL}

Holotype: BMNH2008.5.2.3. Tonga, Tongatapu, outer reef north of Atata Island, north side, Pacific Ocean, $21^{\circ}$ O2 $^{\prime} \mathrm{O}^{\prime \prime} \mathrm{S}$ $175^{\circ} 16^{\prime} 32^{\prime \prime} \mathrm{W}, 24 \mathrm{~m}$, collected by Patrick L. Colin, CRRF, 19 November 1997 (OCDN 5532-W).

Paratype: BMNH 2003.4.10.1: Toachel Mid (K-B Channel), Koror side, Republic of Palau, $07^{\circ} 21.64^{\prime} \mathrm{N} 134^{\circ} 30.17^{\prime} \mathrm{E}$, depth $10 \mathrm{~m}$, collected by Patrick L. Colin, CRRF on 7 April 1998 (OCDN 5532-W).

\section{DESCRIPTION}

Thin encrusting sponge conforming to substrate (Figure $1 \mathrm{G}$ ). Surface rugose, with oscula 5-8 $\mathrm{mm}$ in diameter, with elevated rims and slightly raised areolate porefields up to $8 \mathrm{~mm}$ high. Texture compressible, dense and breaks easily. Colour in life dark green; in preservative dark brown. The sponge exudation makes the alcohol green. Ectosome very thin and not readily separable from underlying choanosome.

\section{SPICULES}

Megascleres. Strongyles: Isodiametric with equally shaped apices, with a few having either bulge or uniform apices. A few malformed, shepherd-staff or crooked strongyles occur, $294.5(260-330) \mu \mathrm{m} \times 2.4(2.4) \mu \mathrm{m}, \mathrm{N}=20$ (Figure $3 \mathrm{G}$ ).

\section{SKELETON}

The choanosomal skeleton is a firm, dense, well developed, irregular polygonal reticulation of chambers divided by very thick reinforced tracts of strongyles, $100-200 \mu \mathrm{m}$ in thickness, with meshes that are $800 \mu \mathrm{m}$ wide (Figure ${ }_{3} \mathrm{H}$ ).

Within and between these layers of thick strongyles the choanosome is much softer, containing the skeleton that consists of an ill-formed, irregular reticulation of strongyles, with no distinction between the primary and secondary tracts. Towards the centre of the choanosome the tracts are more confused and ill-defined, and towards the surface these spicules tend to be vertically arranged, $150 \mu \mathrm{m}$ thick and not diverging into plumose brushes. Scattered throughout the choanosome, between the tracts, are numerous strongyles. Strongyles also encircle the choanosomal chambers. Beneath the ectosome, in the subectosome, is a thick paratangential-tangential layer of densely interlocking megascleres, approximately $400 \mu \mathrm{m}$ wide. The surface is pierced by a sparse disorganized layer of erect or oblique strongyles.

\section{SUBSTRATE, DEPTH RANGE AND ECOLOGY}

Found on an overhang in reef habitat with a gentle slope to sand and coral rubble, $24 \mathrm{~m}$.
GEOGRAPHICAL DISTRIBUTION

Kingdom of Tonga, Republic of Belau (Palau), Federated States of Micronesia (Figure 4).

\section{ETYMOLOGY}

Named for the type locality.

\section{CHEMISTRY}

Unknown.

\section{REMARKS}

Strongylodesma tongaensis sp. nov. is the second record of the genus from the Pacific Ocean. Geographically, its nearest neighbour is $S$. novaecaledoniae sp. nov. from New Caledonia. Strongylodesma tongaensis sp. nov. differ markedly from $S$. novaecaledoniae sp. nov., in having thinner malformed 'shepherd's crook' strongyles, and in having a thick paratangential to tangential subectosomal layer of densely interlocking megascleres, approximately $400 \mu \mathrm{m}$ wide. Strongylodesma tongaensis sp. nov. is thinly encrusting whereas $S$. novaecaledoniae sp. nov. is almost spherical.

\section{DISCUSSIDN}

Species of Strongylodesma are now relatively easily recognizable amongst sponge species with strongyles as the only megasclere (Batzella and Prianos), and which lack microscleres or other inclusions. The strongyles in Strongylodesma are arranged in a tangential layer under the ectosome, and form a wide-meshed polygonal reticulation in the choanosome. Species are generally massive, with raised areolate porefields that are either raised and fungiform, or concave. They lack any form of microsclere, and in particular, they lack the anisodiscorhabds that separate them from species of Latrunculia, to which they are very closely related and from which they are impossible to differentiate in the field. Prianos has the skeletal architecture of a chalinid sponge (delicate unispicular isotropic reticulation of strongyles) and is a synonym of Haliclona (Reniera) (de Weerdt, 2002), and the type species of Batzella has skeletal characteristics (plumose columns of strongyles) shared with other Chondropsidae (Van Soest, 2002).

In terms of their secondary metabolite chemistry, species of Strongylodesma contain biologically active discorhabdins and their derivatives (Samaai \& Kelly, 2002; Antunes et al., 2005) that possess the characteristic pyrroloiminoquinone substructure. These compounds are now routinely isolated from species in the latrunculiid genera Latrunculia, Tsitsikamma and Strongylodesma, but have also been identified from various specimens incorrectly identified as Negombata, Batzella, Prianos, Damiria, Histodermella and Zyzzya. A recent taxonomic revision of the genus Latrunculia (Samaai et al., 2006) concluded that only 27 of the 36 species were valid, and a plethora of biologically active compounds were associated with the genus (and family). In this revision, a 'Latrunculia' that produced the macrocyclic lactone latrunculin A, was reassigned to Negombata (family Podospongiidae), while sesterterpene peroxide producing 'Latrunculia' specimens were reassigned to Diacarnus or Sigmasceptrella, also in the family Podospongiidae (Kelly, 2000; Samaai, 2002; Kelly \& Samaai, 2002; Samaai \& Kelly, 2002; Antunes et al., 
2005; Samaai et al., 2006). A sponge identified as Prianos melanos de Laubenfels, 1954, from Okinawa, Japan, is also more correctly identified with Strongylodesma (see Kelly, 2000; Samaai \& Kelly, 2002; Antunes et al., 2005). The prianosins described in this species (Kobayashi et al., 1987, 1991; Cheng et al., 1988; Van Soest et al., 1996) are synonymous with discorhabdins (Perry et al., 1988a, b; Lill et al., 1995; Van Soest et al., 1996), and the sponge had dark brownish pigmentation and strongyles as the only spicules.

\section{Zyzzya versus Latrunculiidae}

Makaluvic acids, damirones and makaluvamines are consistently, but not exclusively, reported from specimens in the genus Zyzzya (Poecilosclerida: Acarnidae, formerly Iophonidae) (see Fu et al., 1996; Kelly, 2000).

A sponge originally identified from Palau as Damiria sp. (Poecilosclerida: Acarnidae) (Stierle \& Faulkner, 1991), and a specimen originally identified from Indonesia as Histodermella sp. (Poecilosclerida: Coelosphaeridae) (Carney et al., 1993), both yielded damirones, makaluvamines and discorhabdins. They were reassigned to Zyzzya fuliginosa by Van Soest et al. (1996) (Poecilosclerida: Acarnidae) on the basis of their shared chemistry and morphological characteristics. Interestingly, makaluvic acids, damirones and makaluvamines, and discorhabdins (common to the Latrunculiidae) have now also been isolated from a South African latrunculid species Cyclacanthia bellae Samaai \& Kelly, 2004. The discovery of a new pyrroloiminoquinone alkaloid (tsitsikammamine) that is biosynthetically intermediate to the makaluvamines of Zyzzya (Kelly, 2000; Samaai \& Kelly, 2002; Antunes et al., 2005) and the discorhabdins of the Latrunculiidae, has also been isolated from Tsitsikamma favus Samaai \& Kelly, 2002.

Makaluvic acids, damirones, and makaluvamines, common to species of Zyzzya (Poecilosclerida: Acarnidae), and discorhabdins, common to species of Latrunculia, Strongylodesma, and Tsitsikamma (Poecilosclerida: Latrunculiidae), have been found in some species of Zyzzya and Cyclacanthia (Poecilosclerida: Latrunculiidae), indicating affinity between these genera. The discovery of tsitsikammamine, biosynthetically intermediate to makaluvamines and discorhabdins, also isolated from Tsitsikamma favus, adds support for this affinity (Perry et al., 1988a, b; Kelly, 2000; Samaai \& Kelly, 2002) and confirms that the pyrroloquilonine alkaloids are a strong consistent chemotaxonomic marker for these genera (see also Kelly, 2000; Samaai \& Kelly, 2002; Antunes et al., 2005). The majority of known species of Zyzzya and Latrunculiidae also share an intensely dark brownish-black base coloration to which may be overlaid an oily purplish, greenish, and blueish sheen. Zyzzya and latrunculid genera share a similar general skeletal structure of tracts of diactinal megascleres that form polygonal cells ranging from wispy to firm honey-comb-like structures (see Samaai \& Kelly, 2002), and some species of Latrunculia and Strongylodesma have an acanthose terminus on the megascleres (Zyzzya has acanthose strongyles and tylotes with acanthose termini). The genera also share specialized areolate quiferous structures.

The combination of these chemical and morphological characters across various Latrunculiidae genera and Zyzzya in Acarnidae suggest that the genus Zyzzya might, at the very least, be reassigned to suborder Latrunculina, and at best, to within family Latrunculiidae. However, Zyzzya has palmate isochelae, not found in any latrunculid genus, and fully acanthose strongyles, indicating that a careful comparison of Zyzzya to other Acarnidae is warranted before any further action is taken.

In summary, at present eight species of Strongylodesma are known to exist worldwide, four of which have been described from South Africa and the South Atlantic. Even though a rich and diverse sponge fauna exists within the south-west Atlantic, Indian Ocean, Mediterranean, New Zealand and Australia (evident from the extensive literature and inventories on sponges) (e.g. Lévi, 1964; Bergquist, 1965, 1968; Bergquist \& Fromont, 1988; Kelly-Borges \& Bergquist, 1988; Hooper \& Lévi, 1993; Pulitzer-Finali, 1993; Van Soest, 1994; Hooper \& Wiedenmayer, 1994; Colin \& Arneson, 1995; Kelly-Borges \& Valentine, 1995; Kelly, 1997; Hooper et al., 2000), the genus has never been recorded from these localities. Strongylodesma has a low degree of diversity and disparity amongst its few characters, but differences may be recognized in the size-range variation and shape distinction of the strongyles, external coloration, habitat, gross morphology and the conspicuously distinct variations in the choanosomal skeleton.

The most speciose and diverse regions for Strongylodesma from a biogeographical perspective is the surrounding waters of South Africa (Samaai et al., 2003, 2004). The occurrence of the genus in the Caribbean, the south-west Pacific and the south-east Atlantic and its possible absence in the south-west Atlantic, the eastern Pacific, and the surrounding waters of Australia and New Zealand represent a widely disjunct distribution of the genus across the centre of the Pacific and Atlantic Oceans. The discovery of the new species $S$. purpureus sp. nov. and S. nigra sp. nov. in the Caribbean extends the distribution of this genus further north within the Atlantic Ocean and it is also a first record of this genus for this region. An explanation for the known distribution of Strongylodesma is difficult and future efforts are required to search for additional outlying species and populations to precisely define the distribution limits of the general distribution of the genus. The observation that the genus appears to be absent from most of the subtropical/warm temperate southwest Atlantic favours the scenario that the Caribbean or New Caledonian species are basal lineages in the Strongylodesma clade, with South African species probably being more derived as a consequence of a later divergence.

\section{ACKNDWLEDGEMENTS}

The authors thank the National Research Foundation, South Africa, for financial support to the first author, and are grateful for access to the Electron Microscopy Unit at the University of Kwa-Zulu Natal. This work was supported by the National Research Foundation, South Africa (Grant number FA 2004043000058), and in New Zealand by the Foundation for Research Science \& Technology (Contract Co1X0219) to the National Institute of Water \& Atmospheric Research (NIWA). Ongoing research support to M.K. and C.S.S. through Capability Funding to the Biodiversity Programme, from NIWA, is gratefully acknowledged. We thank Lori Bell and Dr Patrick Colin, Coral Reef Research Foundation, for collection of new Tongan material. Collections by the Coral Reef Research Foundation were made under contract to the United States National Cancer 
Institute Contract No. No1-CM-27704. The Koror State and the Bureau of Marine Resources, Republic of Palau, and the Government of Tonga granted CRRF permits for collection. This work was supported by NIWA Aquatic Biodiversity and Biosecurity Programme. This paper is a contribution from the Coral Reef Research Foundation, Palau, Micronesia.

\section{REFERENCES}

Antunes E.M., Beukes D.R., Kelly M., Samaai T., Barrows L.M., Marshall K.M., Sincich C. and Davies-Coleman M.T. (2004) Pyrroloiminoquinones from four South African latrunculid sponges. Journal of Natural Products 67, 1268-1276.

Antunes E.M., Copp B.R., Davies-Coleman M. and Samaai T. (2005) Pyrroloiminoquinone and related metabolites from Marine sponges. Natural Products Report 22, 62-72.

Bergquist P.R. (1965) The sponges of Micronesia, Part 1. The Palau Archipelago. Pacific Sciences 19(2), 123-204.

Bergquist P.R. (1968) The marine fauna of New Zealand: Porifera, Demospongiae. Part 1 (Tetractinomorpha and Lithistida). New Zealand Oceanographic Institute Memoirs 37, 1-100.

Bergquist P.R. and Fromont J.P. (1988) The marine fauna of New Zealand: Porifera, Demospongiae. Part 4 (Poecilosclerida). New Zealand Oceanographic Institute Memoirs 96, 1-197.

Carney J.R., Scheuer P.J. and Kelly-Borges M. (1993) Makaluvamine G, a cytotoxic pigment from an Indonesian sponge Histodermella sp. Tetrahedron 49, 8483-8486.

Cheng J., Ohizuma Y., Walchli M.R., Nakamura H., Hirata Y., Sasaki T. and Kobayashi J. (1988) Prianosins B, C and D, novel sulfurcontaining alkaloids with potent antineoplastic activity from the Okinawan sponge Prianos melanosv. Journal of Organic Chemistry $53,4621-4624$.

Colin P.L. and Arneson C. (1995) Tropical Pacific invertebrates. A field guide to marine invertebrates occurring on tropical Pacific Coral reefs, seagrass beds and mangroves. Irvine, USA: Coral Reef Press, pp. 296.

Fu X., Ng P.L., Schmitz F.J., Hossain M.B., Van der Helm D. and Kelly-Borges M. (1996) Makaluvic acids A and B: novel alkaloids from the marine sponge Zyzzya fuliginosus. Journal of Natural Products 59, 1104-1105.

Gunasekera S.P., McCarthy P.J., Longley R.S., Pomponi S.A., Wright A.E., Lobkovsky E. and Clardy J. (1999) Discorhadbin P, a new enzyme inhibitor from a deep-water Caribbean sponge of the genus Batzella. Journal of Natural Products 62, 173-175.

Gunasekera S.P., Zuleta I.A., Longley R.E., Wright A.E. and Pomponi S.A. (2003) Discorhabdins S, T, and U, new cytotoxic pyrroloiminoquinones from a deep-water Caribbean sponge of the genus Batzella. Journal of Natural Products 66, 1615-1617.

Hooper J.N.A. and Lévi C. (1993) Axinellida (Porifera: Demospongiae) from the New Caledonia Lagoon. Invertebrate Taxonomy 7, 1395-472.

Hooper J.N.A. and Battershill C.N. (1998) Order Poecilosclerida. In Lévi C. (ed.) Sponges of the New Caledonia lagoon. Paris: ORSTOM, collection Faune et Flore Tropicales, Volume 33, pp. 1-214.

Hooper J.N.A. and Wiedenmayer F. (1994) Porifera. In Wells A. (ed.) Zoological catalogue of Australia. Volume 12. Melbourne: CSIRO Australia, xiii, pp. 1-621.

Hooper J.N.A., Kelly M. and Kennedy J.A. (2000) A new Clathria (Porifera: Demospongiae: Microcionidae) from the Western Indian Ocean. Memoirs of the Queensland Museum 42, 427-444.
Hoshino T. (1981) Shallow-water Demosponges of Western Japan. 2. Journal of Science of the Hiroshima University (B) 29, 207-289.

Kelly-Borges M. and Bergquist P.R. (1988) Sponges from Motupore Island, Papua New Guinea. Indo-Malayan Zoology 5, 121-159.

Kelly-Borges M. and Valentine C. (1995) The sponges of tropical island region of Oceania: a taxonomic status review. In Maragos J.E., Peterson M.N.A., Eldredge L.G., Bardach J.E. and Takeuchi H.F. (eds) Marine and coastal biodiversity in the Tropical Island Pacific Region. Volume 1-species systematics and information management priorities. Chapter 6. Program on environment. Honolulu, Hawai: East-West Center.

Kelly M. (1997) Porifera. Sponges. In Richmond M.D. (ed.) A guide to the seashores of Eastern Africa and the western Indian Ocean Islands. Sweden: Sida, Department for Research Cooperation, SAREC. Ord \& Vetande AB: Sweden, pp. 106-117.

Kelly M. (2000) Distribution of the pyrroloquinolines. In Urban S., Hickford S.J.H., Blunt J.W. and Munro M.H.G. (eds.) Bioactive marine alkaloids. Current Organic Chemistry 4, 765-807.

Kelly M. and Somaai T. (2001) Family Podospongiidae. In Hooper J.N. and Soest R.W.M. (eds) Systema Porifera. A guide to the supra specific classification of sponges. Volume 1. New York: Kluwer Academic/ Plenum Publishers, pp. 694-202.

Keyzers R.A., Samaai T. and Davies-Coleman M.T. (2004) Novel pyrroloquinoline ribosides from the South African latrunculid sponge Strongylodesma aliwaliensis. Tetrahedron Letters 45, 9415-9418.

Kobayashi J., Cheng J.F., Isibashi M., Nakamura H., Ohizuma Y., Hirata Y., Sasaki T., Lu H. and Clardy J. (1987) Prianosin A, a novel antileukemic alkaloid from the Okinawan sponge Prianos melanos. Tetrahedron Letters 28, 4939-4942.

Kobayashi J., Cheng J.F., Yamamura S. and Isibashi M. (1991) Revised structures of prianosins $\mathrm{C}$ and $\mathrm{D}$, antineoplastic alkaloids from the Okinawan marine sponge Prianos melanos. Tetrahedron Letters 32, $1227-1228$.

Laubenfels M.W.de. (1954) The sponges of the West Central Pacific. Oregon State College Monographs-Studies in Zoology 7, 1-320.

Lévi C. (1964) Spongiaires du canal de Mozambique. Bulletin du Muséum National d'Histoire Naturelle série 2 36, 384-395.

Lévi C. (1969) Spongiaires du Vema Seamount (Atlantique Sud). Bulletin du Muséum National d'Histoire Naturelle, série 2 41, 952-973.

Lévi C. (1998) (ed.) Sponges of the New Caledonian lagoon. Paris: ORSTOM, collection Faune et Flore Tropicales, Volume 33, pp. 1-214.

Lill R.E., Major D.A., Blunt J.W. and Munro M.H.G. (1995) Studies on the biosysnthesis of discorhabdin B in the New Zealand sponge Latrunculia sp. B. Journal of Natural Products 58, 306-311.

Perry N.B., Blunt J.W. and Munro H.M.G. (1988a) Cytotoxic pigments from New Zealand sponges of the genus Latrunculia: discorhabdins A, B and C. Tetrahedron 44, 1727-1734.

Perry N.B., Blunt J.W., Munro H.M.G., Higa T. and Sakai R. (1988b) Discorhaddin D, an antitumour alkaloid from the sponges Latrunculia and Prianos sp. Journal of Organic Chemistry 53, 41274128.

Pulitzer-Finali G. (1993) A collection of marine sponges from East Africa. Annali del Museo Civico di Storia Naturale G Doria 89, 247-350.

Sakemi S., Sun H.H., Jefford C.W. and Bernardinell G. (1989) Batzellines A, B and C. Novel pyrroloquilonine alkaloids from the sponge Batzella sp. Tetrahedron Letters 30, 2517-2520.

Samaai T. (2002) Systematics of the Family Latrunculiidae Topsent (Porifera: Demospongiae) and consideration of the diversity and biogeography of shallow-water sponges of western South Africa. Volume 2. $\mathrm{PhD}$ thesis. University of the Western Cape, unpublished. 
Samaai T. and Kelly M. (2002) Family Latrunculiidae. In Hooper J.N.A. and Van Soest R.W.M. (eds) Systema Porifera. A guide to the supraspecific classification of sponges. Volume 1. New York: Kluwer Academic/Plenum Publishers, pp. 708-719.

Samaai T., Gibbons M.J., Kelly M. and Davies-Coleman M. (2003) South African Latrunculiidae (Porifera: Demospongiae: Poecilosclerida): descriptions of new species of Latrunculia du Bocage, Strongylodesma Lévi, and Tsitsikamma Samaai \& Kelly. Zootaxa 371, 1-26.

Samaai T., Keyzers R. and Davies-Coleman M. (2004) A new species of Strongylodesma Lévi, 1969 (Porifera, Demospongiae, Latrunculina, Latrunculiidae) from Aliwal Shoal on the east coast of South Africa. Zootaxa 584, 1-11.

Samaai T. and Gibbons M. (2005) Demospongiae taxonomy and biodiversity of the Benguela region on the west coast of South Africa. African Natural History 1, 1-96.

Samaai T., Gibbons M.J. and Kelly M. (2006) Revision of the genus Latrunculia du Bocage, 1869 (Porifera: Demospongiae; latrunculiidae) with descriptions of new species from New Caledonia and the Northern pacific. Zootaxa 1127, 1-71.

Soest R.W.M. Van. (1984) Marine sponges from Curaçao and other Caribbean localities. Part III. Poecilosclerida. In Hummelinck P.W. and Van der Steen L.J. (eds) Uitgaven van de Natuurwetenschappelijke Studiekring voor Suriname en de Nederlandse Antillen. No. 112. Studies on the Fauna of Curaçao and other Caribbean Localities 66, 1-167.

Soest R.W.M. Van. (1994) Sponges of the Seychelles. In van der Land J. (ed) Oceanic reefs of the Seychelles: report on a cruise of RV Tyro to the Seychelles in 1992 and 1993. Leiden: Museum of Natural History, Leiden, pp. $65-74$.
Soest R.W.M. Van. (2002) Family Chondropsidae Carter, 1886. In Hooper J.N.A. and Van Soest R.W.M. (eds) Systema Porifera. A guide to the supraspecific classification of sponges. New York: Kluwer Academic/Plenum Publishers, pp. 521-527.

Soest R.W.M. Van., Braekman J.C., Faulkner D.J., Hajdu E., Harper M.K. and Vacelet J. (1996) The genus Batzella: a chemosystematic problem. Bulletin de l'Institute Royal des Sciences Naturelle de Belgique 66, 89-101.

Stierle D.B. and Faulkner D.J. (1991) Two new pyrroloquinoline alkaloids from the sponge Damiria spec. Journal of Natural Products 54, $1131-1133$.

Sun H.H., Sakemi S., Burres N. and McCarthy P. (1990) Isobatzellins A, $\mathrm{B}, \mathrm{C}$ and D. Cytotoxic and antifungal pyrroloquilonine alkaloids from the marine sponge Batzella sp. Journal of Organic Chemistry 55, $4964-4966$

and

Weerdt W. de. (2002) Family Chalinidae Gray, 1886. In Hooper J.N.A. and Van Soest R.W.M. (eds) Systema Porifera. A guide to the supraspecific classification of sponges. Volume 1. New York: Kluwer Academic/Plenum Publishers, pp. 852-873.

\section{Correspondance should be addressed to:}

T. Samaai

Marine and Coastal Management

Ecosystem Utilisation and Conservation

Private Bag X 2

Roggebaai 8012

Cape Town

South Africa

email: tsamaai@deat.gov.za 